\title{
WHAT IS LABOR'S
}

\section{TRUE PURPOSE?}

\section{The Implications of SEIU's Unite to Win Proposals for Organizing}

ON DECEMBER 2, 2004, NEARLY FIVE HUNDRED PEOPLE CROWDED INTO THE CUNY Graduate Center auditorium in New York City to listen to labor leaders debate the future of the labor movement at the "Labor at the Crossroads" conference cosponsored by the Queens College Labor Resource Center and New Labor Forum. They came because the labor movement is in a real state of crisis, and because, for the first time in a very long while, there is a genuine debate going on in the labor movement about the kind of transformation required to rebuild labor's strength, power, and vision in today's economy.

That labor is in a crisis cannot be questioned. While there may be some labor leaders who are content to keep ministering to an ever less powerful, shrinking base, there were few in the room that day that would disagree with the words expressed by SEIU International Executive Vice President Gerry Hudson on the opening panel, that the U.S. "labor movement is becoming dangerously close to being too small to matter."

For the first time in decades, both organizing activity and union membership numbers have dropped precipitously. Where in past years unions had to organize 500,000 new workers just to keep union density stable, this year unions may have to organize as many as 800,000 new workers just to stand still. And they will not even come close. In fact, after a 
year when unions shifted enormous resources away from organizing towards electoral politics, it is likely that we will see the lowest organizing gains we have seen in more than two decades, possibly fewer than 200,000 new workers overall. Worse yet, this has occurred at a time when we are faced with the most labor unfriendly political and legal climate that we have seen in nearly a century. As Bill Fletcher noted in his opening remarks at the conference, this is indeed "the winter of our discontent."

\section{OPENING THE DEBATE}

T IS IN THIS CONTEXT THAT IN NOVEMBER 2004

SEIU President Andy Stern posted his "Unite to Win: 21st Century Plan to Build New Strength for Working People" on the internet, and the debate began. Less a blueprint than a list of recommendations, SEIU put out a full package-website, PowerPoint presentation, and ongoing blog discussion, encouraging a point-counterpoint from the entire labor movement. ${ }^{1}$ Some of the recommendations are not particularly controversial-these include recommending a national AFL-CIO campaign to reestablish the right to organize free from employer interference and to gain access to quality health care for all Americans, and that U.S. unions unite with unions from other countries by industry, sector, and craft, to build a global labor movement that has power to taken on multinational employers. Other recommendations include that the AFL-CIO should devote more resources to its political member mobilization fund, that labor councils should be required to have strategic plans for political action and supporting organizing campaigns, that affiliates be required to support and join local labor councils, and that the AFL-CIO and af- filiates have concrete goals and training programs to ensure that the diversity of their membership is reflected in their staff, leadership, and other decision making bodies. Unite to Win also recommends that the AFL-CIO use \$25 million dollars in annual royalties from Union Plus credit card purchases to set up a center to stop the "Wal-Marting" of American jobs.

But it is the recommendations relating to the restructuring of the AFL-CIO to unite workers into unions by industry, sector, or craft, and reduce the number of unions through mergers and consolidations that have provoked the most debate. First, Stern proposes that for each industry, craft, or employer, the AFL-CIO Executive Council should have the authority to recognize up to three lead national unions. Lead unions will get 50 percent of their per capita dues returned to them by the AFL-CIO each year and must plan to use at least 10 percent of revenue for organizing by 2006,15 percent by 2008 , and 20 percent by 2010.

In addition, Stern argues that the AFL-CIO should have the authority to force or prevent mergers, revoke charters, require coordinated bargaining, and transfer bargaining responsibilities in the interest of concentrating union strength and density in primary crafts, employers, or industries.

To date the AFL-CIO has been a strictly voluntary organization whose sole authority has been to mediate disputes and, in rare circumstances, revoke charters. The Unite to Win recommendations would involve significant increases in the nature and extent of AFL-CIO power and authority. Yet, at the same time, the per capita "give backs" would most likely result in massive reductions in AFL-CIO revenues, operations, and staff. Thus, the restructuring plan seems to be left with the internal contra- 
diction that comes from dramatic increases in authority hamstrung by the loss of the resources necessary to exercise that authority meaningfully.

The recommendations relating to restructuring the AFL-CIO build on a piece first drafted by SEIU Building Services Director Steve Lerner in $2002 .{ }^{2}$ For Lerner the key point is that density matters, and unions do best when they focus their energies on organizing and bargaining and gaining density in their core jurisdictions, and do worst when they engage in what he calls "general worker" unionism, when they organize anyone who comes along and have no density, power, or experience in any particular jurisdiction. Thus, Lerner argues the only way for the U.S. labor movement to recover its strength and power through organizing is to consolidate into large sectoral or industry unions. The Unite to Win proposal provides the mechanisms through which the AFLCIO can be restructured in order to encourage the kinds of industry-based unions and strategic organizing that Lerner was suggesting.

There is a great deal of merit in much of what first Lerner and then Stern put forward. First and foremost it has generated desperately needed debate. For more than two decades, we have been dancing around the edge of what is necessary for the U.S. labor movement to really "change to organize." It has always been about the quest for the silver bullet, but it has never been about the kinds of fundamental cultural, philosophical, strategic, political, and yes, structural transformation, that will be necessary for this labor movement to truly rise again. The Unite to Win proposal has opened up a space wide enough to provoke the kinds of discussions that are necessary if any real change is going to occur.

\section{BEYOND STRUCTURE}

$\mathbf{T}$ HERE IS NO QUESTION THAT INCREASING UNION power in the United States depends in part on unions using density where they have it and increasing union density where they do not. This means that organizing success depends on unions choosing organizing targets where they can use their density directly, through bargaining leverage to restrain the employer's antiunion campaign or to get the employer to agree to card check neutrality, or indirectly through leverage with unionized suppliers, customers, or current or potential investors. There is also no question that current corporate structures more often than not require taking on entire firms and industries in intensive multisite and sometimes multicountry organizing campaigns such as the one being waged by UNITE HERE! and the Teamsters with CINTAS, or the campaigns that CWA has run in wireless, or SEIU in the building security industry. Yet most U.S. unions, particularly in some of our highest union density industries in the manufacturing, transportation, or entertainment sectors, fail to capitalize on union density in their primary sectors when it comes to organizing new workers.

It is also true that when unions move into industries outside their primary jurisdictions in search of easier election victories these efforts do nothing to stop the erosion of density within their primary industries or strengthen their bargaining power in already organized units. Instead, they expend precious resources in an environment where they may be able to win elections more easily but have neither the density nor experience in the industry to bargain effectively for and represent the unit after 
the election is won. It also distracts them from focusing on the critical task of increasing union density within their primary industries.

Yet, union power is about more than density, resources, jurisdiction, and structure. There are many unions that stick to one jurisdiction, or even have density in that jurisdiction, but have no power because they failed to capitalize on that density when it came to a critical moment in organizing or bargaining. We only need to look back to lost strikes in heavily organized industries in the 1980s, such as the UPIU strike at International Paper, to remember that density is not everything. ${ }^{3}$ Winning the strike at International Paper required taking that density and coupling it with a full commitment to a comprehensive strategic campaign, something UPIU was not prepared to do.

Nor is it a simple matter of bigger is always better, or that shifting resources to organizing improves organizing success. Talking about density, resources, jurisdiction, and structure, as the Unite to Win proposal does, absent a real discussion of strategy, purpose, and vision leaves out the power and soul of the movement.

As Bill Fletcher explained in his remarks at the conference, "We are not focusing on the core question: it is not structure, it is purpose, in other words, a question of what is or should be the essence of trade unions in the current situation in which we live. The essence is class struggle, or, as A. Phillip Randolph so eloquently and diplomatically got it, social uplift. In other words, can the trade union movement truly lead a movement for social transformation?"

Just as the Kerry campaign failed to pro- vide American voters with enough of a vision to overcome their fear of terror or their economic insecurity, the labor movement has to

\section{... it is ironic that [the}

\section{SEIU] propose[s] a plan} that is so provocative on ... restructuring the AFLCIO yet silent on ... U.S. foreign policy. stand for something worth fighting and hoping for. We have to be organizing for something and it needs to be more than that lowest and safest common denominator-“a voice@work." If we are going to be challenging a ruthlessly antiunion, right-wing government that is closely aligned with some the world's largest multinationals, we are indeed going to have to be using the language and strategy of power and transformation, and it is going to take a lot more than restructuring the AFL-CIO to get us there. Instead, it is going to take getting in front on the issues that really matter to American workers and workers around the world.

One of those key issues is building a global labor movement. However, particularly given the legacy of AIFLD, a Unite to Win proposal that includes building a global labor movement as one of its tenets, but does not address the AFL-CIO's silence on the war in Iraq or other major U.S. foreign policy issues such as the Kyoto accords or the World Court, is still talking about moving the furniture but not transforming a movement. SEIU can and should be commended for having spoken out 
against the war from the beginning; thus it is ironic that they propose a plan that is so provocative on the sensitive area of restructuring the AFL-CIO yet silent on the fundamental subject of U.S. foreign policy.

We must also be careful when talking about building a global labor movement that we are not simply focusing on building a one-sided movement to help U.S. workers organize. If U.S. unions are going to seek the support of unions and nongovernmental organizations around the globe, they are going to have to become more engaged in strengthening unions everywhere, not just here at home. Thus, it was disappointing to see the Wal-Mart question framed in the Unite to Win proposal in terms of saving U.S. jobs rather than as part of a global campaign to stop the worldwide race to the bottom that WalMart represents. For, unless and until Wal-Mart is organized as part of a global campaign, the jobs of workers in every country who produce goods sold at Wal-Mart (which includes almost anything consumers buy) will see a spiraling down in their wages, benefits, and working conditions, and union organizing efforts in every country will be undermined.

However, organizing Wal-Mart cannot be done piecemeal. It will require a very carefully crafted multicountry, multi-industry, comprehensive campaign, targeting not just individual WalMart stores, but the entire Wal-Mart network worldwide. It will also require simultaneously going after the major manufacturers who produce the myriad of goods that are sold at Wal-Mart, which includes everything from household and sporting goods, to groceries and appliances. Organizing Wal-Mart will also require shifting away from the demonizing of Chinese workers and unions that produce goods sold at Wal-Mart, that has so dominated the strategy of many U.S. unions.

And this is not just the case with WalMart. The task of organizing in manufacturing, high tech, and other more mobile sectors of the economy must become the responsibility of the entire labor movement. Because, absent that support, global capital will continue to use the threat of global outsourcing to push down wage and benefit standards, and break unions in the best jobs in our economy. If those jobs become substandard and go nonunion, service and public sector jobs will follow. Thus it becomes imperative that the struggle to organize in these industries and to fight for fair global trade and investment policies become the struggle of service and public sector unions as well. This should in-

\section{... it was disappointing to} see the Wal-Mart question framed in the Unite to Win proposal in terms of saving U.S. jobs rather than as part of a global campaign to stop the worldwide race to the bottom... 
the manufacturing and high tech sectors not just in this country but around the globe.

\section{BUILDING THE VISION}

J UST AS WE NEED TO HAVE A VISION THAT CHALlenges U.S. foreign policy, the labor movement must speak to a more transformative vision at home. While the U.S. labor movement has fought hard to increase minimum wage and preserve overtime pay, it seems to have ceded control of the hours and pace of work to the employer. American workers are exhausted by twelve-hour days, mandatory overtime, sevenday weeks, cross training, and job combinations. Yet the labor movement has difficulty addressing these issues because they are present in union contracts in almost every sector. If unions are going to do right by unorganized workers and convince them that organizing into a union will make a real improvement in their work lives, then they will have to address the fact that these increases in the hours and pace of work are hurting workers and their families. Just as much now as one hundred years ago, workers want roses as well as bread. Because if it is just about paying time and a half, then many employers will be willing to pay the difference if that is what it takes to avoid a union. But if it is about regaining control over staffing, the quality of care, or the pace, scheduling, and hours of work-those are the issues that really can transform workers' lives and are worth fighting for, but unions will have to take the lead. Ironically, part of the key to SEIU's organizing success is that they have so effectively tapped into these fundamental issues in their own organizing campaigns, particularly among health care workers. Somehow, the vision that has been so central to their own organizing success is missing from the roadmap that they lay out for the rest of the labor movement.

Another problem with the focus on structure is that changing structure in the absence of changing strategy is not real change. The Unite to Win plan makes cursory mention of the need to focus on unorganized sectors, occupations, or regions, but offers no strategy or institutional will to go with it. For example, restructuring of the AFL-CIO is going to do nothing about the fact that no AFL-CIO affiliate sees the finance sector or private sector office workers as its primary jurisdiction. Yet, among the more than eight million workers employed in the finance sector, most of them office workers, union density averages only two percent. ${ }^{4}$ These are workers in an expanding part of our economy whose organization is critical to the

\section{[Labor] seems to have ceded control of the hours and pace of work to the employer.}

future of our labor movement, but they seem to have been left out of every unions' organizing plan. Rather than simply fighting over the highly coveted turfs of health care or the public sector, any plan to revitalize the AFL-CIO also needs to address the difficult subject about how we would fund, facilitate, and staff the organizing of growth areas, such as the financial sector, that no union is currently targeting.

We find a similar limitation in the Unite to Win focus when we look at labor's seeming 
failure to make significant organizing gains in that great swath of red states in the South. It is true that a significant portion of labor's difficulty in organizing in the South can be attributed to the fact that it is the region of the country that has been hit hardest by global outsourcing. Even unions that have organized there successfully for decades, such as UNITE, have watched their hard won gains turn to bitter losses as tens of thousands of union jobs leave each year for Mexico and China. ${ }^{5}$

However, that only tells part of the story. Based on my research, I have found that those unions that have been successful in organizing in the South, such as SEIU, UNITE, or CWA, have been those willing to make a commitment to building relationships with communities of color. ${ }^{6}$ This commitment has included a willingness to hire organizers of color and develop rank-and-file leaders of color among the workers being organized, and to build relationships with community groups and clergy in the African American, Haitian, and Hispanic community. Thus, if the labor movement is to make any significant headway in organizing the South, or for that matter, the Southwest, then it is imperative they make a commitment to diversity that has real goals and benchmarks and is closely tied with leadership development.

While it is true that the Unite to Win proposal includes language committed to diversity in leadership and staff positions that is reflective of the membership, absent a full commitment to leadership development and the resources and follow-up that goes with it, the language about diversity included in the Unite to Win proposal becomes just that-languageand will not contribute to transforming the la- bor movement, or changing to organize. Because if unions don't have leadership development and membership education, then they eliminate the possibility of a vision, because that

... among the more than

eight million workers ... in the finance sector ... union density averages only two percent.

is where visions are built.

Unions also cannot forget that their ability to organize depends directly on how effective they have been at making significant gains at the bargaining table where they are already organized. CWA Executive Vice-President Larry Cohen is correct when he stated in his response to the Unite to Win proposal that the "inner life" of the union matters. They have to spend as much energy making sure they get good contracts, and build power between contracts, because if they don't empower current membership, they will start losing old members-through broken contracts, decertifications, and lost strikes-as fast as they organize new ones. At the same time, in this period of crisis, the "inner life" cannot become the sole focus, because if unions do not face the crisis, do not push for some greater vision, and do not organize aggressively, globally, and on a massive scale, we are in danger of becoming "too small to matter."

Unfortunately, instead of moving forward, the debate has become somewhat sidetracked by finger pointing about union democracy and political motivations. There is no union in the 
AFL-CIO that can rest on its laurels, nor is there any union that has cornered the market on union democracy. Most of the leaders on both sides of this debate came into the labor movement in the 1970s and 1980s fresh from the civil rights, antiwar, and/or welfare rights movements. They were trained in the language of empowerment, the organizer as catalyst, invisible when the task was done. But somewhere along the way the vision of empowerment and social and economic justice seems to have gotten replaced with a model of tactical mobilization. Now, when union leaders most need both the humility of honest introspection and selfcriticism, as well as the courage to truly challenge global capital and reshape a global movement, the greatest risk is that they will stumble on the swords of their own pride and arrogance.

We need this debate. We also need to remember that our purpose as a movement is about more than density and structure. It is about social and economic justice, it is about roses as well as bread, it is about taking on global capital, and it is about making fundamental changes in the lives of working people here and around the world.
1. See $h t t p: / / w w w . u n i t e t o w i n . o r g$ for a detailed listing of the SEIU proposals and responses from other unions.

2. See Steve Lerner "Three Steps to Reorganizing and Rebuilding the Labor Movement: Building New Strength and Unity for All Working Families." http://www.labornotes.org/archives/2002/12/e.htm/ and Steve Lerner, "An Immodest Proposal: Rebuilding the House of Labor," New Labor Forum Vol. 12, Issue 2 (2003): pp. 9-34.

3. Julius Getman, The Betrayal of Local 14,
(Ithaca: Cornell University Press, 1998).

4. http://data.bls.gov/labjava/outside.jsp? survey $=$ ce.

5. For a more detailed discussion of this issue see http://www.ilr.cornell.edu/international/ downloads/News/UsccCornell-umassReport.pdf

6. Kate Bronfenbrenner and Robert Hickey. "Changing to Organize: A National Assessment of Union Organizing Strategies," in Organize or Die:Labor's Prospects in Neoliberal America, edited by Ruth Milkman and Kim Voss, (Ithaca: Cornell University Press, 2004). 